\title{
SIGNIFICANCE OF THE URINARY EXCRETION OF CELLS AFTER EXPERIMENTAL MEDULLARY NECROSIS
}

BY

\author{
D. J. DAVIES, A. KENNEDY, AND P. GAIL SALUJA \\ From the Department of Pathology, The University, Liverpool 3
}

Necrosis of the renal pyramid is a well-recognized feature of the renal disease caused by prolonged heavy consumption of common analgesics. Recently it has been shown that damage of the renal papilla leading to necrosis is the primary event in this condition (Dawborn, Fairley, Kincaid-Smith, and King, 1966; Burry, de Jersey, and Weedon, 1966; Sanerkin, 1966; Kincaid-Smith, 1967).

The nephrotoxicity of aspirin, phenacetin, and other related compounds has been investigated in human subjects by measuring the effect of these drugs on the rate of renal cell excretion in the urine (Harvald, Valdorf-Hansen, and Nielsen, 1960; Prescott, 1966). Although analgesics raise the rate of excretion of renal cells, the significance of this in terms of altered renal histology is not known. However, in studies of rats with necrosis of the proximal convoluted tubules caused by mercuric chloride, it was found that the rate of urinary cell excretion was a sensitive method of detecting renal tubular damage (Davies and Kennedy, 1967, a, b). Before the results of this type of investigation can be used in assessing analgesic nephrotoxicity it is important to know how well renal medullary damage can be correlated with an increase in the rate of excretion of renal cells.

Ethyleneimine (vinylamine) is a compound that produces selective damage of the renal pyramid (Levaditi, 1901; Mandel and Popper, 1951). In this paper experiments are described in which the changes in renal cell excretion observed after giving this compound are correlated with the histological changes in the kidney and also with the renal concentrating power.

*Requests for reprints to Dr. A. Kennedy at the above address.
Material and Methods

Two types of experiment were performed:

\section{Experiment 1}

This was designed simply to compare the cell excretionrate observed in the first 48 hours after injecting ethyleneimine with the histological severity of the medullofy 90 damage. In this experiment 36 rats were used. Urime samples were collected over 5-hour periods on to consecutive days to obtain a base-line value for the cello excretion rate. Thirty rats were then given a dose of ethy-o leneimine intraperitoneally which ranged from $0.0005 \frac{\mathrm{Q}}{\mathrm{O}}$ to $0.002 \mathrm{ml} . / 100 \mathrm{~g}$. (Table I), while the remaining six, $\varrho$ which were controls, received a dose of saline. 5-hour $\overrightarrow{\vec{O}}$ urine samples were collected on the two days after the 3 injection. Then the animals were killed and the kidneys? removed for histological examination.

\section{Experiment 2}

The histological changes and the changes in celloexcretion rate were correlated with the maximum con 3 . centrating capacity of the kidney as a means of indicating the severity of the renal medullary damage after a single injection of ethyleneimine.

In this experiment thirty rats were used. In addition to the 5-hour urine samples for the purpose of cell $\$$ counting, the urine passed during the remainder of the 24 hours was also collected. After depositing the cells N from the 5-hour sample the supernatant was pooled withthe urine for the rest of the day and the volume and N osmolarity of the 24-hour urine was determined.

After 2 days during which base-line values for cell $\omega_{\sigma}^{\omega}$ excretion rates and 24-hour urinary volumes and osmolarities were obtained, a dose of one unit vasopressin?

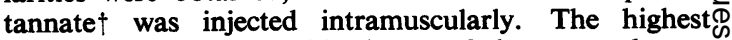
urinary osmolarity noted in the next 2 days was taken as.indicating the maximum concentrating capacity. After

†"Pitressin tannate in oil". Parke Davis and Co. Ltd. 
an interval of 3 days the cell excretion rates and urinary osmolarities were determined again to ensure that they had returned to their base-line values. 22 rats were then injected with ethyleneimine in doses ranging from 0.0005 to $0.002 \mathrm{ml} / 100 \mathrm{~g}$. as in Experiment 1 ; the other eight were injected with saline and acted as controls. Daily determinations of the cell excretion rate were made as before. When a cell excretion rate in an experimental animal had been normal for 2 consecutive days, an injection of one unit vasopressin tannate was again given, and the osmolarity and cell excretion rate were observed for the next 24 hours. Every time an animal or group of animals was given the second dose of vasopressin, at least one of the control animals also received a dose of the same vasopressin. 48 hours after receiving the second dose of vasopressin the animals were killed and the kidneys removed for histological examination.

Technical Details.-Male Sprague-Dawley rats weighing from 200 to $300 \mathrm{~g}$. were used throughout. They were kept in individual stainless steel metabolism cages and were fed on powdered Diet 41B (Oxo Ltd.) with fresh tap water ad libitum. The ethyleneimine was injected in the form of a freshly-prepared 1 per cent. ( $v / v)$ solution in sterile distilled water.

The cells in the 5-hour urine sample were counted by the method of Prescott and Brodie (1964). The sample was concentrated by centrifugation and the cells stained by a mixture of 2-7 diamino fluorene and phloxine $B$ to distinguish renal cells from polymorphonuclear leucocytes. The volume of the sample was adjusted to one tenth of that of the original 5-hour specimens, and the cells were counted in a modified Neubauer bright line counting chamber.

The urinary osmolarities were determined on $0.3 \mathrm{ml}$. samples by cryoscopy using a Knauer semi-micro osmometer. Highly concentrated specimens were diluted with an equal volume of distilled water to bring them within the range of the instrument.

The blocks of the kidney were fixed in formol corrosive for 12 to 18 hours and were then trimmed. Paraffin sections passing through the apex of the papilla were cut and stained with haematoxylin and eosin.

\section{Results}

\section{Experiment 1}

The lesions observed were divided into three grades of severity according to the following criteria:

Grade III.-The entire renal pyramid was necrotic (Fig. 1). Occasionally there was some involvement of the inner intermediate zone.

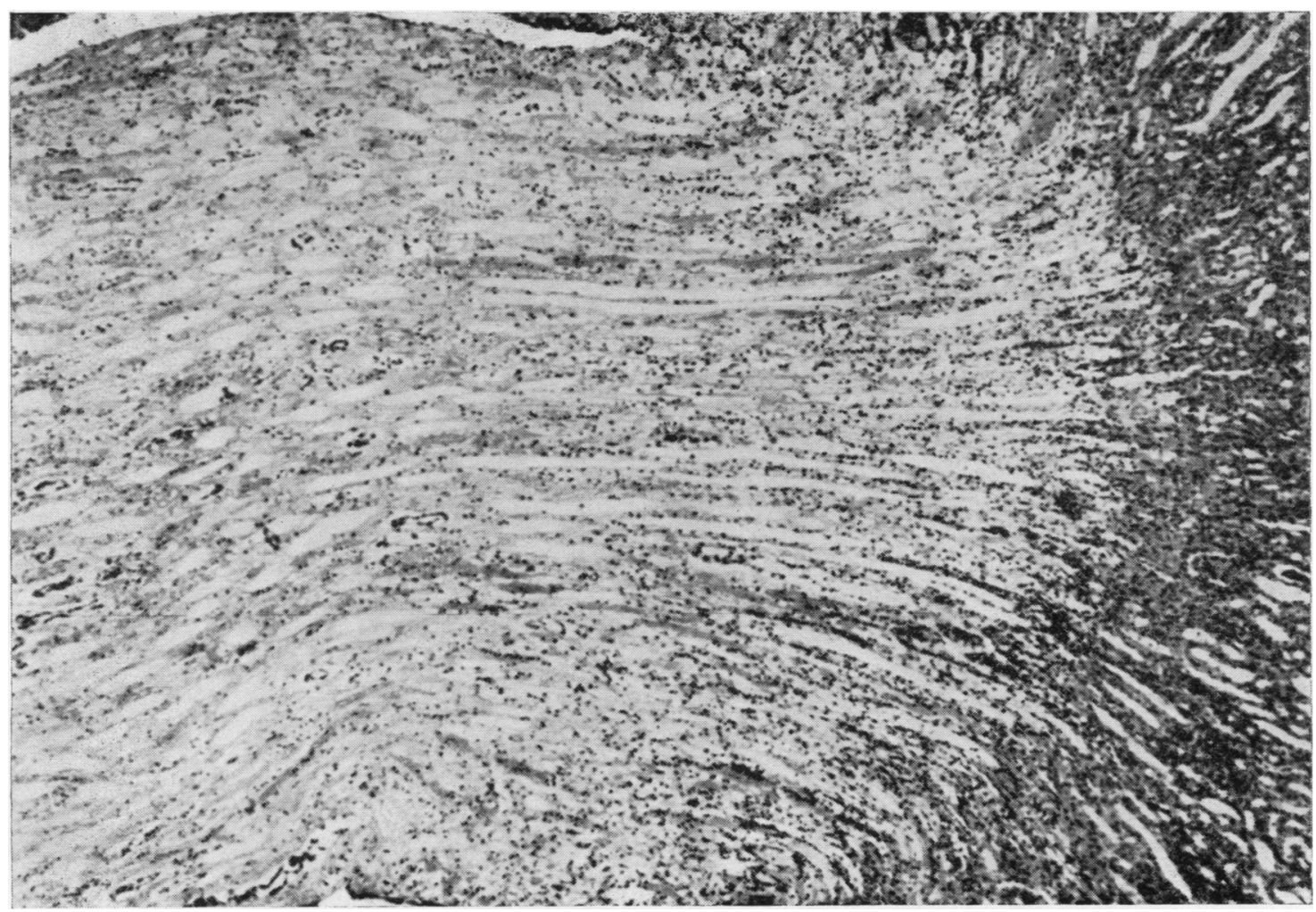

Fig. 1.-A Grade III lesion 2 days after a dose of $0.002 \mathrm{ml} / 100 \mathrm{~g}$. ethyleneimine. The entire renal pyramid is necrotic and there is some extension of the lesion into the intermediate zone Haematoxylin and eosin. $\times 225$. 
Grade II.-There was necrosis of the renal pyramid, but it was incomplete and involved only the distal part of the pyramid (Fig. 2).

Grade I.-Necrosis of the pyramid was absent but the interstitium of the pyramid was infiltrated by eosinophilic exudate. Colloid casts were present in tubular lumina (Fig. 3, opposite).

Grade 0.-Animals injected with ethyleneimine which had histologically normal kidneys.

TABLE I

EXPERIMENT I. NUMBER OF RATS SHOWING EACH GRADE OF HISTOLOGICAL LESION AND RELATIONSHIP OF LESIONS TO DOSAGE OF ETHYLENEIMINE

\begin{tabular}{|c|c|c|c|c|c|}
\hline \multirow{2}{*}{$\begin{array}{c}\text { Dose of } \\
\text { Ethyleneimine } \\
\text { (ml./100 g.) }\end{array}$} & \multicolumn{4}{|c|}{ Grade of Lesions } & \multirow{2}{*}{ Totals } \\
\hline & $\mathbf{0}$ & I & II & III & \\
\hline 0.00025 & 3 & 3 & - & - & 6 \\
\hline 0.0005 & - & 6 & - & - & 6 \\
\hline 0.001 & - & 1 & 6 & 5 & 12 \\
\hline 0.002 & - & - & - & 6 & 6 \\
\hline Totals & 3 & 10 & 6 & 11 & 30 \\
\hline
\end{tabular}

DOSE OF ETHYLENEIMINE RELATED TO GRADE OF 꿍 LESION (Table I).-A dose of ethyleneimine of $0.00025 \mathrm{ml} . / 100 \mathrm{~g}$. failed to produce any lesion in half of the rats given this dose while a dose of $\frac{\square}{\omega}$. $0.002 \mathrm{ml} . / 100 \mathrm{~g}$. always produced Grade III lesions. Between these limits the effect could not be predicted $\underset{\vec{S}}{\vec{S}}$ with certainty. A dose of $0.005 \mathrm{ml} . / 100 \mathrm{~g}$. caused Grade I or II lesions, and a dose of $0.001 \mathrm{ml} / 100 \mathrm{~g}$. Grade II or III lesions.

Grade of Lesion related to Rate of Cell $\vec{\circ}$ EXCRETION(Table II, opposite).-During the base-line $\vec{\overrightarrow{ }}$ period the cell excretion rates were generally between ${ }_{\sigma}$ 2,000 and 5,000 cells per hour. They never exceeded the rate of 10,000 cells per hour and were usually appreciably less. As in previous investigations, we $V$ have regarded 10,000 cells per hour as the upper iv limit of normal. After the injection of ethyleneimine $\vec{\omega}$ the cell counts in the three animals with Grade 0 O lesions did not differ from their base-line values or from those in control groups.

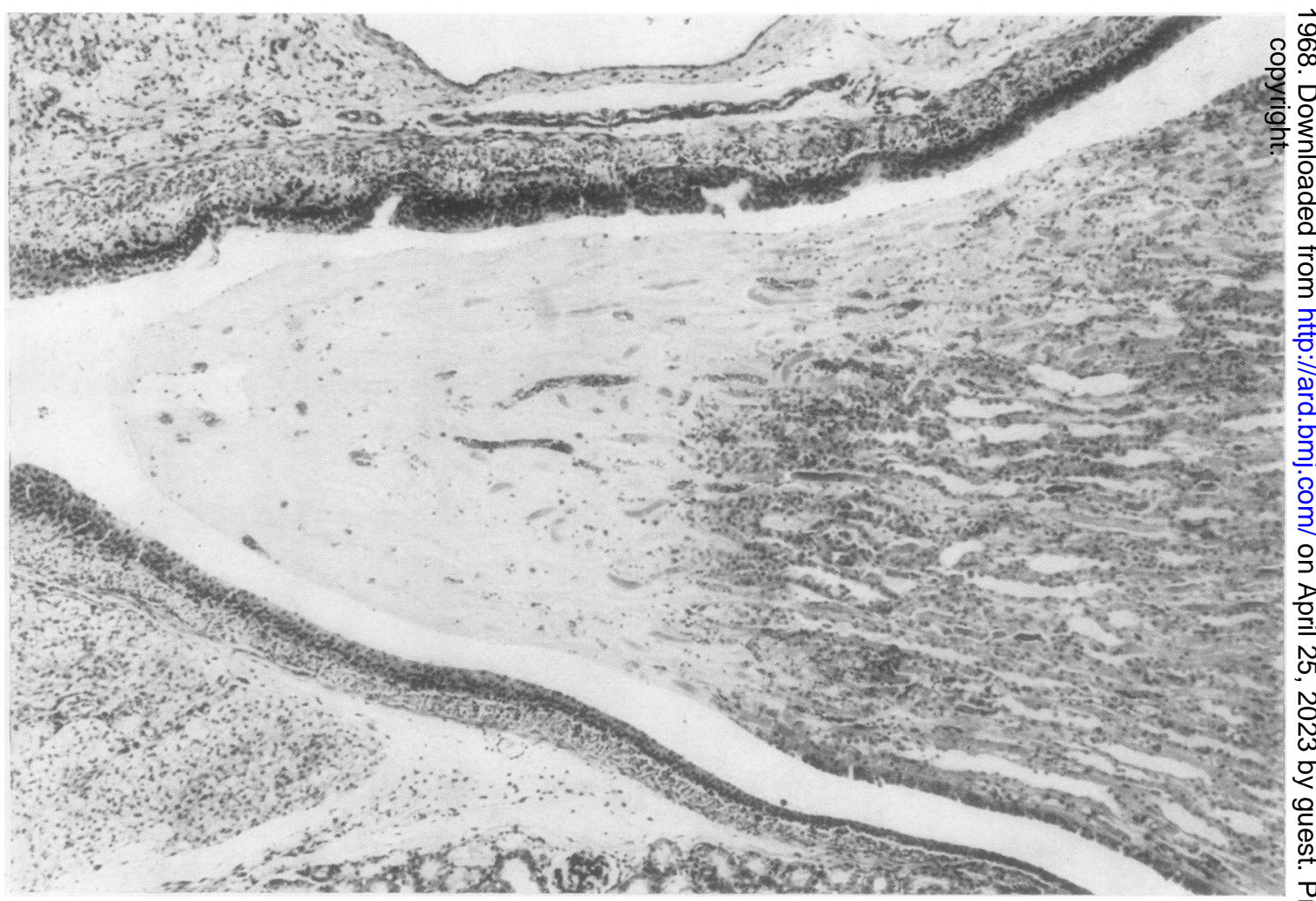

Fig. 2.-Grade II changes 2 days after a dose of $0.001 \mathrm{ml} / 100$ g. ethyleneimine. The tip of the papilla is necrotic. Haematoxylin and eosin. $\times 225$. 


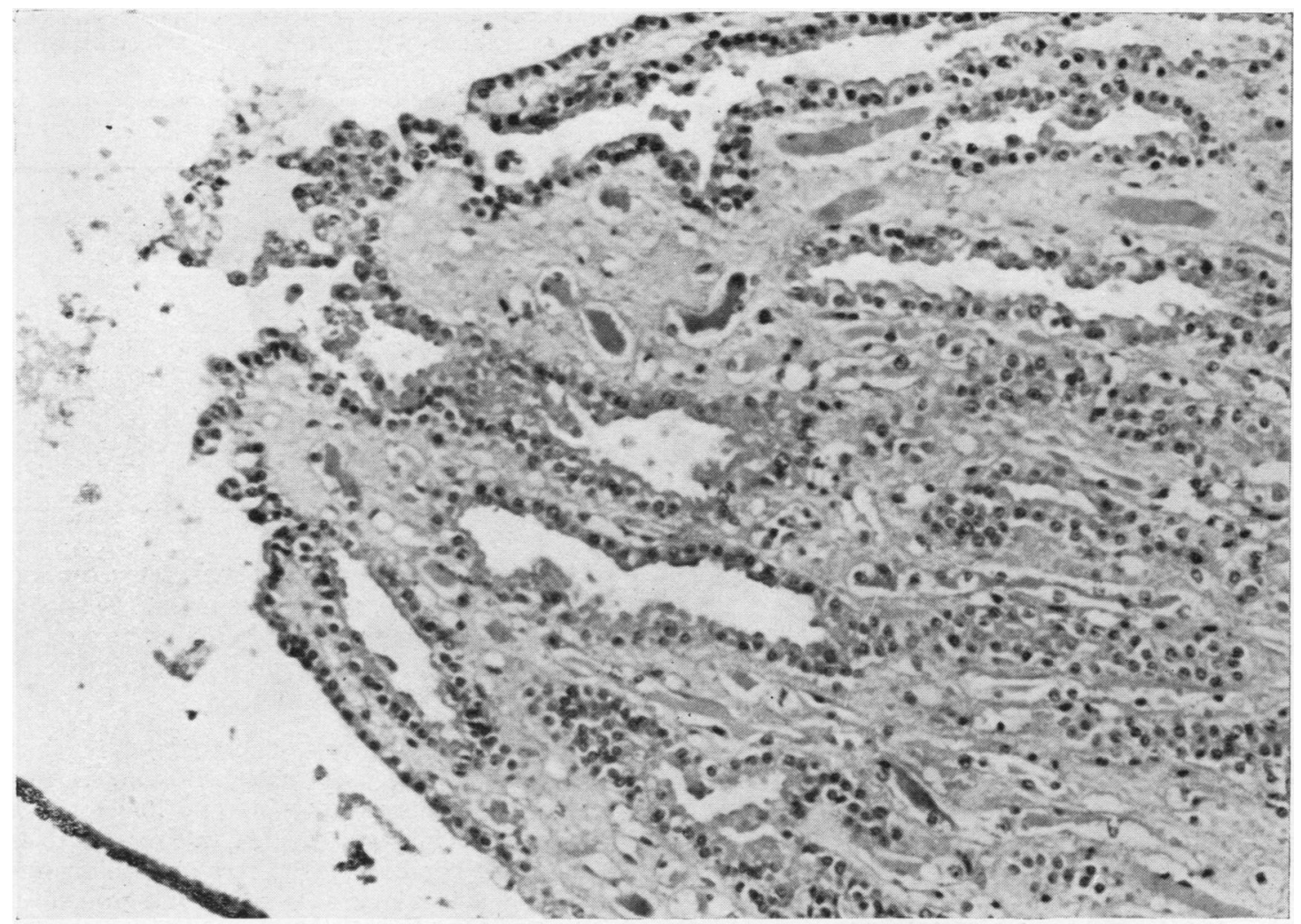

Fig. 3.-Grade I changes in the renal papilla of a rat given $0.0005 \mathrm{ml} / 100 \mathrm{~g}$. ethyleneimine 2 days previously. There is no necrosis but many casts are present. Haematoxylin and eosin. $\times 560$

TABLE II

EXPERIMENT 1. RESPONSE OF URINARY CELL EXCREEXPERIMENT 1. RESPONSE OF URINARY CELL EXCRE-
TION RATES IN THOUSANDS PER HOUR TO INJECTION OF ETHYLENEIMINE

\begin{tabular}{|c|c|c|c|c|c|}
\hline \multirow{3}{*}{$\begin{array}{c}\text { Severity } \\
\text { of } \\
\text { Lesion }\end{array}$} & \multirow{3}{*}{$\begin{array}{l}\text { No. } \\
\text { of } \\
\text { Rats }\end{array}$} & \multicolumn{4}{|c|}{ Day of Experiment } \\
\hline & & \multicolumn{2}{|c|}{ Before Injection } & \multicolumn{2}{|c|}{ After Injection } \\
\hline & & 1 & 2 & 3 & 4 \\
\hline Controls & 6 & $\begin{array}{c}4.5 \\
( \pm 3 \cdot 0)\end{array}$ & $\begin{array}{c}3 \cdot 5 \\
( \pm 3 \cdot 9)\end{array}$ & $\begin{array}{c}2 \cdot 8 \\
( \pm 1 \cdot 2)\end{array}$ & $\begin{array}{c}4 \cdot 3 \\
( \pm 2 \cdot 8)\end{array}$ \\
\hline Grade 0 & 3 & $\begin{array}{c}4 \cdot 0 \\
( \pm 1 \cdot 9)\end{array}$ & $\begin{array}{c}1 \cdot 8 \\
( \pm 0 \cdot 64)\end{array}$ & $\begin{array}{c}3 \cdot 7 \\
( \pm 1 \cdot 6)\end{array}$ & $\begin{array}{c}2 \cdot 8 \\
( \pm 0.85)\end{array}$ \\
\hline Grade I & 10 & $\begin{array}{c}2.9 \\
( \pm 1.4)\end{array}$ & $\begin{array}{c}3 \cdot 6 \\
( \pm 2 \cdot 5)\end{array}$ & $\begin{array}{c}7 \cdot 3 \\
( \pm 4 \cdot 8)\end{array}$ & $\begin{array}{c}3 \cdot 5 \\
( \pm 2 \cdot 9)\end{array}$ \\
\hline Grade II & 6 & $\begin{array}{r}2.4 \\
( \pm 1.4) \\
\end{array}$ & $\begin{array}{r}2 \cdot 4 \\
( \pm 1 \cdot 3) \\
\end{array}$ & $\begin{array}{r}9.9 \\
( \pm 3 \cdot 9) \\
\end{array}$ & $\begin{array}{r}6 \cdot 5 \\
( \pm 3 \cdot 2) \\
\end{array}$ \\
\hline Grade III & 11 & $\begin{array}{r}3.0 \\
( \pm 1 \cdot 9) \\
\end{array}$ & $\begin{array}{r}2 \cdot 5 \\
( \pm 1 \cdot 4) \\
\end{array}$ & $\begin{array}{c}25 \cdot 3 \\
( \pm 18 \cdot 0) \\
\end{array}$ & $\begin{array}{c}43 \cdot 8 \\
( \pm 23 \cdot 5) \\
\end{array}$ \\
\hline \multirow{4}{*}{\multicolumn{2}{|c|}{$\begin{array}{l}\text { Significance of } \\
\text { Differences from } \\
\text { Control Group }\end{array}$}} & & 0 & NS & NS \\
\hline & & & I & $\mathrm{P}<0.02$ & NS \\
\hline & & & II & $P<0.01$ & NS \\
\hline & & & III & $P<0.05$ & $P<0.01$ \\
\hline
\end{tabular}

NS $=$ not significant
In the animals with Grade I and II lesions the mean cell excretion rates did not exceed 10,000 per hour, but on the first day after the injection they were higher than their base-line values and in a few individual cases the counts exceeded 10,000 cells per hour.

Only in the animals with Grade III lesions was there a marked increase in the rate of cell excretion after ethyleneimine. This was increased both 24 and 48 hours after the injection. The highest excretion rate observed was 80,000 cells per hour.

\section{Experiment 2}

Obvious histological changes could be seen in the kidneys of all animals given ethyleneimine in this experiment. Each animal could therefore be classified according to the severity of the lesion into one of the four grades described in Experiment 1 except that no Grade 0 lesions were found as the very low dose of ethyleneimine was not used. The kidneys of all the control animals were histologically normal. 
Controls.-The cell excretion rates remained normal throughout (Fig. 4). Small rises were sometimes observed after an injection of vasopressin.

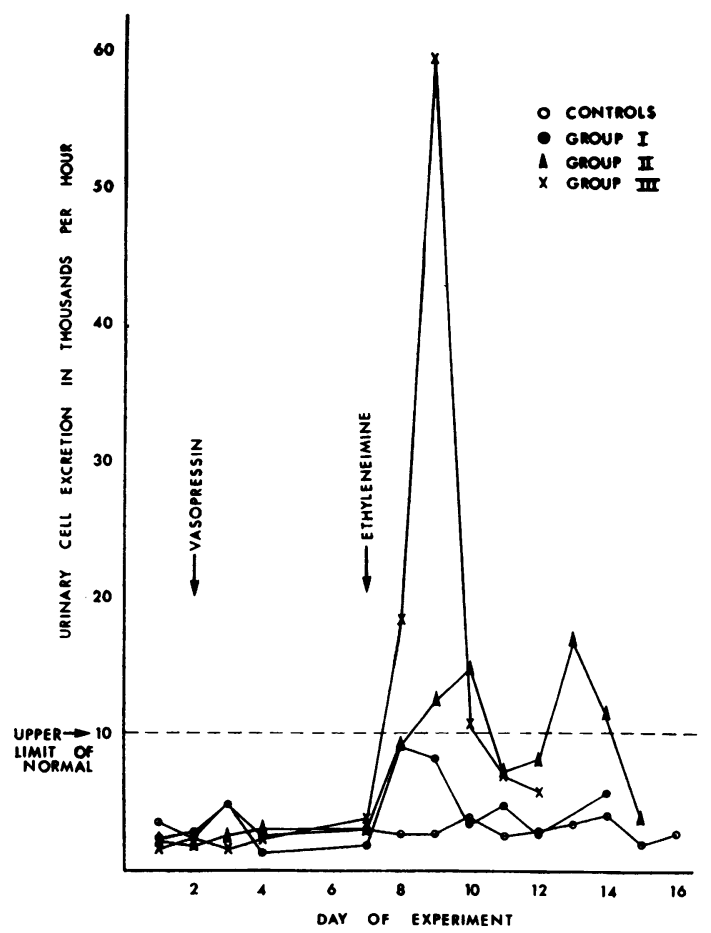

Fig. 4.-Experiment 2. The changes in renal cell excretion rates of groups of rats with different grades of papillary damage.

No significant difference was observed between the maximum concentrating capacity observed before the saline injection and that seen afterwards (Table III).

Grade I.-A slight rise in the mean cell excretion rate was observed during the $\mathbf{4 8}$ hours after ethyleneimine, but the mean value never exceeded 10,000 cells per hour. Four individual rats in this group exceeded this figure, the highest excretion rate achieved being 18,500 cells per hour. This group showed significant impairment of renal concentrating power after ethyleneimine. The mean maximum osmolarity attained was 1,140 milliosmols/litre compared with 2,000 milliosmols/ litre before the injection. Only one rat in this group died before the end of the experiment.

Grade II.-The mean cell excretion rate became elevated above the upper limit of normal on the second and third day after the injection but was normal again on the fourth day (Fig. 4, Day 11). Six rats in this group died before the experiment
TABLE III

RELATIONSHIP BETWEEN DEGREE OF PAPILLARY DAMAGE AND CONCENTRATING CAPACITY OF KIDNEYS

The figures given are the maximal urinary concentrations, in Milliosmols/1., reached within 48 hours of a dose of Vasopressin Tannate in oil

\begin{tabular}{l|c|c|c}
\hline $\begin{array}{c}\text { Severity of } \\
\text { Renal Lesion }\end{array}$ & $\begin{array}{c}\text { Before } \\
\text { Ethyleneimine }\end{array}$ & $\begin{array}{c}\text { After } \\
\text { Cell Excretion } \\
\text { had returned } \\
\text { to Normal }\end{array}$ & $\begin{array}{c}\text { Significance } \\
\text { of } \\
\text { Difference }\end{array}$ \\
\hline Controls & $\begin{array}{r}2,080 \\
( \pm 245)\end{array}$ & $\begin{array}{c}2,320 \\
( \pm 290)\end{array}$ & NS \\
\hline Grade I & $\begin{array}{r}2,000 \\
( \pm 279)\end{array}$ & $\begin{array}{r}1,140 \\
( \pm 310)\end{array}$ & $\mathbf{P}<0.001$ \\
\hline Grade II & $\begin{array}{r}1,950 \\
( \pm 282)\end{array}$ & $\begin{array}{r}774 \\
( \pm 44)\end{array}$ & $\mathbf{P}<0.001$ \\
\hline Grade III & $\begin{array}{r}4850 \\
( \pm 244)\end{array}$ & $\mathbf{P}<0.001$ \\
\hline
\end{tabular}

could be completed, but the maximum concentrating capacity was determined in the remaining five. Significant impairment of urine concentration was present, the mean maximum osmolarity achieved being only 920 milliosmols/litre.

Grade III.-All had high cell excretion rates as in Experiment 1. The mean peak cell excretion rate was 60,000 cells per hour within 48 hours of the injection. The highest individual rate recorded wag 106,000 cells per hour. The mean excretion rates. was normal 2 days later. All rats in this group die within 5 days of injecting the ethyleneimine, and it was possible to determine the maximum urinary osmolarity in only two cases. Severe impairment of urinary concentrating power was present in both, the maximum osmolarity achieved being only 430 and 530 milliosmols/litre.

The maximum osmolarity in each group before and after ethyleneimine and in the controls is shown in Table III and the cell excretion rates in Fig. 4.

\section{Discussion}

These results show that when the renal pyramid is damaged by ethyleneimine there is an increased rate of excretion of renal cells in the urine and the extent of the initial increase is proportional to the severity of the damage.

Measurement of increases in cell excretion rates do not, however, seem to be the most sensitive or reliable method of detecting damage to the renal pyramid. Many rats died from renal failure at a time when the cell excretion rate was normal or was falling even though a satisfactory volume of urine was still being formed. Also significant impairment of renal concentrating power could be demonstrated when cell excretion rates were normal.

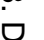


These results are very different from the findings in animals in which necrosis of proximal convoluted tubules had been produced by administration of mercuric chloride (Davies and Kennedy, 1967a, b). In the latter instance a degree of damage almost imperceptible histologically caused a striking increase in the rate of excretion of renal cells and with larger lesions the cell excretion rate exceeded a quarter of a million cells per hour. However, with the pyramidal damage caused by ethyleneimine, a significant rise in the cell excretion rate is often observed only with the largest lesions. Even with a lesion sufficiently severe to cause death, the rate of cell excretion barely exceeds that found with the smallest degree of proximal tubule necrosis. Conversely, a lesion caused by mercuric chloride that resulted in a very high cell excretion rate recovered completely and the presence of complete recovery was indicated by a normal cell count. This is quite different from the results observed with ethyleneimine in the present work. The probable reason for this disparity is the difference in the area of necrotic tubules exposed to the flow of urine; this is much greater in necrosis of the proximal convoluted tubule than in necrosis of the pyramid.

Therefore we must conclude that observations of urinary cell excretion rates are not the most sensitive or reliable method of detecting damage to the renal pyramid, and that determination of the maximum concentrating capacity of the kidney is much more satisfactory.

These conclusions are of some importance when interpreting the results of the experiments in which the nephrotoxicity of analgesics in man has been investigated by observing changes in cell excretion rates. The findings in these experiments and a comparison with the effects of mercuric chloride confirm a previous suggestion that the rate of urinary cell excretion is not only a function of the severity of a renal lesion but also depends upon its site (Kennedy, 1966). If the conclusions that have been drawn from these experiments are applicable to man, then it must follow that a substance which causes the greatest output of cells in the urine is not necessarily the one that produces the most serious renal lesion. Indeed a lesion of some severity may arise in the renal pyramid without causing any appreciable increase in the urinary cell excretion rate. Harvald and others (1960) and Prescott (1966) found that aspirin produced a greater increase in cell excretion in a higher proportion of subjects than phenacetin. From this it has been inferred that, contrary to epidemiological evidence (Sanerkin, 1964), phenacetin may not be the only ingredient of analgesic mixtures that causes renal damage, but that aspirin and possibly caffeine may also be involved. However, because the basic lesion of analgesic nephritis is pyramidal damage, the results of the present experiments suggest that the failure of a substance to increase urinary cell excretion rates in no way absolves it from causing analgesic nephritis. Conversely, a substance producing a rise in renal cell excretion may not cause any harmful or lasting renal damage. Great care must therefore be taken in interpreting urinary cell excretion rates. Particular attention must be paid to locating the site of the renal lesion involved. A study of the nature of the cells excreted in response to a drug may be a valuable factor in deciding what part of the kidney is affected.

\section{Summary}

Lesions of the renal pyramid were produced in male rats by the injection of ethyleneimine. The changes in the urinary excretion of cells were studied and the concentrating power of the kidneys was assessed by measuring the response to vasopressin. These results were related to the histological changes found in the kidneys at the end of the experiment. The changes in cell excretion rates were found to be a poor indicator of the severity of the lesion in the renal pyramid, the renal concentrating power being much better. These results are discussed in relation to analgesic nephritis in man. It is concluded that a substance is not necessarily harmless to the kidney even if it fails to raise the renal cell excretion rate.

We wish to thank the Arthritis and Rheumatism Council for Research for a grant for the purchase of the Knauer Osmometer and the metabolism cages. We are also indebted to Mr. D. Williams for the photography and Mr. B. Hardman and his staff for preparing the histological sections.

\section{REFERENCES}

Burry, A. F., de Jersey, P., and Weedon, D. (1966). Med. J. Aust., 1, 873 (Phenacetin and renal papillary necrosis: results of a prospective autopsy investigation).

Davies, D. J., and Kennedy, A. (1967a). Brit. J. exp. Path., 48, 45 (The excretion of renal cells following necrosis of the proximal convoluted tubule).

- L (1967b). Toxic. appl. Pharmacol., 10, 62 (Course of the renal excretion of cells after necrosis of the proximal convoluted tubule by mercuric chloride). 
Dawborn, J. K., Fairley, K. F., Kincaid-Smith, P., and King, W. E. (1966). Quart. J. Med., 35, 69 (The association of peptic ulceration, chronic renal disease and analgesic abuse).

Harvald, B., Valdorf-Hansen, F., and Nielsen, A. (1960). Lancet, 1, 303 (Effect on the kidney of drugs containing phenacetin).

Kennedy, A. (1966). J. Pharm. Pharmacol., 18, 345 (Contribution to the discussion on "The nephrotoxicity of analgesics", Prescott, L. F. (1966)).

Kincaid-Smith, P. (1967). Lancet, 1, 859 (Pathogenesis of the renal lesion associated with the abuse of analgesics).

Levaditi, C. (1901). Arch. int. Pharmacodyn., 8, 45 (Experimentalle Untersuchungen über die Nekrose der Nierenpapille).

Mandel, E. E., and Popper, H. (1951). A.M.A. Arch. Path., 52, 1 (Experimental medullary necrosis of the kidney. A morphologic and functional study).

Prescott, L. F. (1966). J. Pharm. Pharmacol., 18, 331 (The nephrotoxicity of analgesics).

Prescott, L. F., and Brodie, D. E. (1964). Lancet, 2, 940 (A simple differential stain for urinary sediment).

Sanerkin, N. G. (1964). Brit. med. J., 1, 980 (Phenacetin abused).

- (1966). Brit. J. Urol., 38, 361 (Chronic phenacetin nephropathy. With particular reference to the relationship between renal papillary necrosis and chronic interstitial nephritis).

\section{L'excrétion urinaire des cellules après la nécrose médullaire expérimentale}

\section{RÉSUMÉ}

On a produit des lésions de la pyramide rénale chez des rats mâles par l'injection d'ethylèneimine. On a étudié les altérations de l'excrétion urinaire des cellules et déterminé le pouvoir de concentraction des reins en évaluant la réponse à la vasopressine. On a examiné les résultats ainsi obtenus à la lumière des altérations histologiques trouvées dans les reins à la fin de l'expérience. On a trouvé que les altérations du taux de l'excrétion cellulaire correspondaient peu à la sévérité de la lésion de la pyramide rénale, et plus au pouvoir de concentration du rein. On discute ces résultats à propos de la néphrite humaine due aux antalgiques. On conclut qu'une substance n'est pas nécessairement inoffensive au rein par le fait qu'elle n'augmente pas le taux d'excrétion de la cellule rénale.
La excreción urinaria de las células después de la necrosis $\vec{\omega}$ medular experimental

\section{Sumario}

Se produjeron lesiones de la pirámide renal en ratas masculinas por inyecciones de etilenoimina. Se estudiaron las alteraciones de la excreción urinaria celular y se $\stackrel{\rho}{\supset}$ estableció el poder de concentración renal por la deter- $\vec{\theta}$ minación de la respuesta a la vasopresina. Se examinaron of los resultados asi obtenidos a la luz de las alteraciong $\infty$ histológicas halladas en los riñones al cabo de la experiencia. Se observó que las alteraciones de las cifras excreción celular correspondieron menos a la gravedą de la lesión de la pirámide renal y mucho más al poder $\bar{\partial}$ de concentración del riñon. Se discuten estos resultados en relación con la nefritis humana debida a productos $\bar{D}$ analgésicos. Se concluye que una substancia no es $\varrho$ inofensiva al riñon por el solo hecho de no aumentar las tasa de excreción de la célula renal. 